\title{
Spratly Archipelago as a Potential Reserve Recovery of Biodiversity in Coastal and Island Reefs of Vietnam
}

\author{
Yu.Ya Latypov \\ A.V. Zhirmunsky Institute of Marine Biology FEB RAS, 690059, Vladivostok \\ ltpv@mail.ru
}

\begin{abstract}
In the broad sense of the Spratly Islands, reefs are ecologically important, with abundant and relatively unexploited resources where placed in the depression of coastal areas still exist in large numbers. Itproposed to establish cross-border international maritime reserve zone (Park Reserve) Spratly under possible protectorate of Vietnam, China and the Philippines.
\end{abstract}

Keywords Spratly Archipelago, Biodiversity, Corals, Marine Reserve

\section{Introduction}

In the Spratly archipelago are approximately about 600 coral reefs and atolls, scattered in the South China Sea north of the Philippine Islands in Sabah to southern Palawan and over distances of more than $500 \mathrm{~km}$. Reefs, raised above the sea surface in the maximum tide, include at least seven 26 islands and rising rocks[1], 1994). Itu Aba and Taiping is lands, is one of the largest is lands of the archipelago.

However, full information on the reefs of the archipelago, the composition and distribution of hermatypic scleractinian is not enough. Known unpublished records of Soviet-and Russian-Vietnamese expeditions[2] at scientific vessel "Callisto" and "Academic Oparin (1981 and 2007 respectiv ely), multip le publications in the Vietnamese language[3-6] and conferences [7,8].

Indopacific province, which includes the Spratly archipelago, characterized by high diversity of marine life. There found at least 80 genera of hermatypic cora $1 \mathrm{~s}[9,10]$. In its coral reef ecosystem found over 400 species of coral[11], 1989), 1500 species of reef fish and 200 species of marine algae[1]. The exact number of all marine animals and plants in the South China Sea, it is difficult to assess because of inadequate state of taxono mic data, but the total number of species that are found at all depths from Spratly reef and is likely to approach such as Indopacific and numbered several thousand species. Coral reefs are common in the shallow waters of the South China Sea. High spatial diversity and productivity of coral reefs provide not only a variety of

* Corresponding author:

ltpv@mail.ru (Yu.Ya Latypov)

Published online at http://journal.sapub.org/ms

Copyright (C) 2012 Scientific \& Academic Publishing. All Rights Reserved habitats for marine organisms, but also the existence of juvenile fish larvae for fisheries, shellfish, crustaceans, cephalopods and other animals. Because corals play a key role in marine ecosystems of the South China Sea need a better understanding of the role of the coral fauna in the region for marine resource conservation and management in the future.Therefore, the purpose of this work was the study of coral reef communities as part of Vietnam's Spratly coral fauna of the South China Sea.

\section{Material and Methods}

In different years $(1981,2005,2007)$ using SCUBA were studied composition and distribution of scleractinian and mass species macrobenthos, community structure in each zone of reefs. Иссле дованияпроводилисьнапятиостровах: Lodd $\left(111^{\circ} 40^{\prime} \mathrm{E}, 8^{\circ} 39^{\prime} \mathrm{N}\right)$, Nam Yet $\left(114^{\circ} 22^{\prime} \mathrm{E}, 10^{\circ} 10^{\prime} \mathrm{N}\right)$, Sinton $\left(114^{\circ} 22^{\prime} \mathrm{E}, 9^{\circ} 40^{\prime} \mathrm{N}\right)$, Son $\mathrm{Ca}\left(114^{\circ} 30^{\prime} \mathrm{E}, 10^{\circ} 28^{\prime} \mathrm{N}\right)$, Truong Sa $\left(115^{\circ} 45^{\prime} \mathrm{E}, 10^{\circ} 25^{\prime} \mathrm{N}\right)$. Work performed on a common methodology with the use of hydrobiological accounting framework and transects[12]. Along the $100-$ 200 meter's using frames, divided into 100 squares $10 \mathrm{~cm} 2$, assessed the number of speciesbranch, massive, incrusting and funnelform colonies of scleractinian and the degree of coverage of the substrate. The number of colonies of corals recorded at transect, is calculated using the Shannon diversity index using the formula $\mathrm{H}^{\prime}=-\Sigma$ pi log $\mathrm{Pi}$, where Piis the prevalence of colonies giving generai[13]. The similarities of various communities determined by similarity Serensen[14] and using STATISTICA 6.0.Conducted surveys of the general picture of the landscape in the whole community and Cannon cameras and Olympus. Received more than 500 photographs, which used to characterize the reef and its inhabitants. 


\section{Results and Discussion}

The first studies of coral reefs using SCUBA were held at Spratly in 1981, a jo int Soviet-Vietnamese expedition on the island Sinton. The results of these studies are given in an unpublished report[2] and two publications in the Vietnamese language[15, 16]. Were briefly describes the structure of the reef, are lists of scleractinian, including 108 species belonging to 40 genera. At the end of the 90 -ies of the last century on reefs in the archipelago were Vietnamese and Vietnam-Philippine expedition. Appreciation expressed for the characterization of different types of reefs, coral distribution characteristics are analysed. Are lists of species of Cnidarians, consisting in total of 121 up to 201 of scleractinian, Alcyonarian, Gorgonarian and hydroid coral[17, 5, 6]. In 2005, 2007 was researchedatoll Lodd in joint Russian-Vietnamese expedition to the scientific vessel "Akademik Oparin".

The species diversity on Spratly reef, as on most reefs Indopacific [9, 18], provides representatives of five genera: Acropora (42 species), Montipora (21), Porites (13), Favia (10), Fungia (8), representing $27.8 \%$ of the total hermatyp ic scleractinian identified in the archipelago.At the islands of archipelago formed four morphological types of reefs: typical for most reefs of Indopacific; reef with short and long reef flat zones; the reefs with steep reef slope; (fig. 1), as well as typical atolls sizes up to $34 \mathrm{~km}$ long and $5 \mathrm{~km}$ wide. In various zones of coral reef species richness varies from 102 to 179 species. The largest number of species observed on the reef slope and in the lagoons of atolls (214 and 190 species respectively). In these same zones usually have the highest degree of substrate cover corals and other related animals (Table 1).In general on reefs in the archipelago discovered 261 species of Scleractinia (Table 2).

The most common were various species of Acropora, Montipora, Pocillopora, and Porites.Continuous coralthicket s Acropora cytherea, A. digitifera, A. cuneata, Pocillopora verrucosa, Montipora speciosa, Porites nigrescens, and $\mathrm{P}$. cylindrica can create monosettlementsan area for many tens of square meters.Multiple species of the reef slope often produces a variety of massive and sub massivecolonies of coral genera Porites, Pocillopora, Goniastrea, Favia, Favites and solitarycolonies AlcyonarianSinularia, Sarcophyton and hydroid corals Millepora (fig. 2).

Almost reefflat zone in most areas commonly found branching colonies Pocillopora damicornis, P. verrucosa, P. eydouxi, Acropora monticulosa andA. gemmifera. Corals A. digitifera, A, palmerae, Faviaspeciosa,Leptoria phrygia, Platygyra lamellina and hydroid Millepora platyphylla to form large colonies in diameter greater than $1 \mathrm{~m}$, providing up to $50 \%$ of the substrate surface. The sand glades of reef flat and reef slopeare many solitary Fungiidae (up to 45 copies./m2) Cy clos eris cy clolites, C. costulata, Fungiafungites, F. scutaria, Sandolitha robusta andHerpolitha limax, providing $30-40 \%$ of the substrate surface.

The vertical sections of the reef slope are generally distributed colony soft corals generaSarcophyton,Lobophyt um, Dendronephthya andgorgonacea Junceella, some of them can reach in diameter $0.5 \mathrm{~m}$.

Usually, the structural form of the atolls observed at lowest ebb. In the median of atolls in the lagoon can be corallogenous lifting type reef flat, which covered with corals at $10-30 \%$, main ly branchyPocilloporaand encrusting Montipora. A similar situation exists with respect to morphology of Thun Tay[7]. Significant areas of lagoons are often busy algae spreading in intertidal areas. Scleractinian here is usually limited. This is a small isolated colony Stylophora, Seriatopora, Favia, Goniastrea, Montipora, Porites, and Gon iopora. The area of the projective cover the bottom of the corals did not exceed 5-7\%. On the inner the reef slope atolls (Thun Tai, Lodd, Sinton, etc.) there is a well-developed coral community with a high content of in the scleractinian generaPocillopora, Acropora, Montipora and Porites (substratecovering-30-50percentage). Here usually dominated by 3-5 species branchy scleractinian Montipora digitata, P. verrucosa, P. nigrescens, Hydnophora exesa, sometimes providing up to $100 \%$ of substrate covering. The reef slope complex in the upper divisions of blue coral Heliopora coerulea, hydroidsMillepora platyphylla, M. dichotoma, massive,plate and encrusting colonies genera Porites, Pachyseris, Echinopora, and Acropora. The area of the projective cover of substrate in the zone of multi-species settlement may be about $100 \%$, deeper $-20-40 \%$.

The overall picture of commun ities is largely similar, but their qualitative and quantitative composition is markedly different. The number of coral species ranges from 102 to 214. How closely the various communities are kept within 24.8-37.5 only in communities of soft soil at the base of the slope of the reef it slightly lower - 11.2-24.6. Complexes of Scleractinian differs small difference degree of similarity, difference extremes $-34.5-41.3$. The taxocene clams how closely do not fall below 32.0 in 50 per cent of commun ities. Reduce the level of similarity, with the largest community's macrophytes dispersion degree of similarity in species from 7.1 to 30.7 . It should be noted that similarities between neighbouring communities one reef higher than similar communities on isolated reefs[18] neighbour.Analysis of Shannon biodiversity index using encountering frequency of coral genera partly reflects biodiversity of coral fauna in study area. Although, length of transect was only $100 \mathrm{~m}$, the number of encountered coral genera was from 17 to 24 genera and biodiversity index is from 0.856 to 1,041 . The respective values for scleractinian corals alone are $0.807-0.934$ and $0.877 \pm 0.044$.

On the reefs of Australia, Vietnam, Indonesia and the Philippines found 360-370 species scleractinian attributed to 70 genera[9, 19]. On reefs Spratly archipelago revealed 261 species of coral, belonging to 66 genera that make up $76 \%$ of the total species scleractinian the entire coral fauna of the Pacific and Indian oceans. Comparison of scleractinian around the descent of wealth and Vietnam's Spratly reveals a high degree of its descent diversity (Table 3). 
Table.1. Maximum degree of substrate covering different organisms and free of macro benthos sites, $\%$

\begin{tabular}{|c|c|c|c|c|}
\hline \multirow{2}{*}{ Components } & \multicolumn{3}{|c|}{ Depth, m } & \multicolumn{3}{c|}{20} & 30 \\
\cline { 2 - 5 } & 10 & 15 & 17.54 & 4.57 \\
Scleractinian & 75.38 & 41.90 & 11.01 & 5.34 \\
Acropora & 40.00 & 33.72 & 21.33 & 12.24 \\
Dead corals & 6.12 & 3.45 & 6.66 & 5.33 \\
Sea grass & 48.81 & 20.03 & 3.73 & 6.19 \\
Calcareous algae & 12.67 & 17.90 & 10.58 & 12.05 \\
Soft corals & 15.50 & 20.52 & 4.70 & 1.08 \\
Sponges & 10.14 & 8.66 & 15.66 & 10.60 \\
Sand & 11.86 & 2.33 & 23.54 & 52.65 \\
Corallogenous limestone & 4.70 & 22.06 & 3.61 & 0.92 \\
Gravel & 0.00 & 11.99 & & \\
\hline
\end{tabular}

Table 2. Taxonomic composition of Scleractinian of the Spratly reef

\begin{tabular}{|c|c|c|c|c|c|c|}
\hline Genera & Lodd & Nam Yet & $\begin{array}{l}\text { Islands } \\
\text { Son Ca }\end{array}$ & Sinton & Truong Sa & $\begin{array}{c}\text { Common number } \\
\text { species }\end{array}$ \\
\hline Acantastrea & + & + & + & - & - & 3 \\
\hline Acropora & + & + & + & + & + & 42 \\
\hline Alveopora & + & + & + & + & + & 3 \\
\hline Anacropra & + & - & + & + & + & 2 \\
\hline Astreopora & + & + & + & + & + & 6 \\
\hline Australogyra & + & - & - & - & + & 1 \\
\hline Balanophyllia & + & - & - & + & + & 2 \\
\hline Barabattoia & + & + & + & - & + & 2 \\
\hline Coeloseris & + & + & + & + & - & 1 \\
\hline Coscinaraea & + & - & + & + & + & 3 \\
\hline Ctenactis & + & + & + & + & + & 1 \\
\hline Cycloseris & + & - & + & - & - & 8 \\
\hline Cynarina & + & - & - & - & - & 1 \\
\hline Cyphastrea & + & + & + & + & + & 4 \\
\hline Dendrophyllia & + & + & + & + & + & 2 \\
\hline Diaseris & + & - & + & - & + & 2 \\
\hline Diploastrea & + & + & + & + & + & 1 \\
\hline Echinophyllia & + & + & + & + & + & 4 \\
\hline Echinopora & + & + & + & + & + & 3 \\
\hline Euphyllia & + & - & + & + & + & 3 \\
\hline Favia & + & + & + & + & + & 10 \\
\hline Favites & + & + & + & + & + & 9 \\
\hline Fungia & + & + & + & + & + & 8 \\
\hline Galaxea & + & + & + & + & + & 2 \\
\hline Gardineroseris & + & + & + & + & + & 1 \\
\hline Goniastrea & + & + & + & + & + & 4 \\
\hline Goniopora & + & + & + & + & + & 6 \\
\hline Halomitra & + & - & + & - & + & 1 \\
\hline Heliofungia & + & - & + & - & + & 1 \\
\hline Herpolitha & + & + & + & + & + & 1 \\
\hline Heterocyathis & + & - & - & + & - & 2 \\
\hline Heteropsamm ia & + & - & - & + & - & 1 \\
\hline Hydnophora & + & + & + & + & + & 3 \\
\hline Isopora & + & + & + & + & + & 2 \\
\hline Leptastrea & + & + & + & + & + & 4 \\
\hline Leptoria & + & + & + & + & + & 1 \\
\hline Leptoseris & + & + & + & + & + & 5 \\
\hline Lithophyllon & + & + & + & + & + & 2 \\
\hline Lobophyllia & + & + & + & + & + & 4 \\
\hline Madracis & + & - & - & + & - & 1 \\
\hline Merulina & + & + & + & + & + & 2 \\
\hline Montastrea & + & + & + & + & + & 3 \\
\hline Montipora & + & + & + & + & + & 21 \\
\hline Moseleya & + & + & - & + & - & 1 \\
\hline Mycedium & + & + & + & + & + & 1 \\
\hline Oulastrea & + & + & + & + & + & 2 \\
\hline Oulophyllia & + & + & - & + & - & 2 \\
\hline Oxypora & + & + & + & + & + & 1 \\
\hline
\end{tabular}




\begin{tabular}{|c|c|c|c|c|c|c|}
\hline Pachyseris & + & + & + & + & + & 3 \\
\hline Palauastrea & + & + & + & + & + & 1 \\
\hline Pavona & + & + & + & + & + & 6 \\
\hline Pectinia & + & + & + & + & + & 3 \\
\hline Physogyra & + & - & - & + & + & 1 \\
\hline Platygyra & + & + & + & + & + & 1 \\
\hline Plesiastrea & + & + & + & + & + & 1 \\
\hline Pleuractis & + & + & + & + & + & 2 \\
\hline Pocillopora & + & + & + & + & + & 4 \\
\hline Podabacia & + & + & + & + & + & 1 \\
\hline Polyphyllia & + & + & + & + & + & 2 \\
\hline Porites & + & + & + & + & + & 13 \\
\hline Psammocora & + & + & + & + & + & 4 \\
\hline Pseudosiderastrea & + & + & + & + & + & 1 \\
\hline Sandalolitha & + & + & + & + & + & 2 \\
\hline Scolymia & + & - & - & - & - & 1 \\
\hline Seriatopora & + & + & + & + & + & 2 \\
\hline Stylocoeniella & + & + & + & + & + & 1 \\
\hline Stylophora & + & + & + & + & + & 2 \\
\hline Symphyllia & + & + & + & + & + & 5 \\
\hline Trachyphyllia & + & - & + & + & + & 1 \\
\hline Tubastrea & + & + & + & + & + & 3 \\
\hline Turbinaria & + & + & + & + & + & 7 \\
\hline
\end{tabular}

Table 3. Generic diversity of Scleract inia in various reefs of Vietnam

\begin{tabular}{|c|c|c|c|c|}
\hline \multirow{2}{*}{ Areas } & \multicolumn{2}{|c|}{} & \multicolumn{2}{c|}{ Value H' } \\
\cline { 2 - 5 } & Number of genera & Variations & Average \\
\cline { 2 - 5 } & $9-17$ & 13.0 & $0.79-0.91$ & 0.67 \\
Central Vietnam & $15-27$ & 18.5 & $0.90-1.20$ & 1.08 \\
Khan' Hoa Province & $15-22$ & 17.6 & $0.81-1.11$ & 0.99 \\
Spratly Archipelago & $10-22$ & 15.5 & $0.67-1.20$ & 0.91 \\
Kon Dao Islands & $6-20$ & 12.5 & $0.60-1.19$ & 0.92 \\
Gulf of Thailand & & & \\
\hline
\end{tabular}

Of course, be further explored Spratly corals species richness increase by not less than 350 species, but now it is safe to say that coral reef fauna is a completely Spratly archipelago in the tropical fauna of the Indopacific.

Stability of coral ecosystems of is lands of the archipelago, its exceptional biodiversity on most reefs provided them uninhabited, i.e. the lack of human influence, and its great distance from the Mainland. Maritime continental ecosystem of the South China Sea can be dependent on the utilization of ecosystems Spratly resume resources larvae. Due to the predominance of monsoon currents[1]Spratly Islands reefs are a source of larvae that replenish disturbed coral reefs in Vietnam. The semi-enclosed nature of the South China Sea and its hydrodynamics characteristics can contribute to the open sea Spratly area with coastal ecosystems to absorb the nutrients. It is likely that the is lands of the archipelago and similar groups of uninhabited reefs provide a mechanism to stabilize the supply of s mall invertebrates and fish to the coastal areas of the South China Sea. Th is is becoming more and more important, because in the coastal areas of Vietnam, Indonesia, Philippines and els ewhere clearly recorded strong overfishing large (adults), invertebrates and fish[1]. The Spratly reefs in the lagoon and reef, especially on elephant are aggregations of many different fish from 37 to 54 spec. $/ \mathrm{m}^{3}$ (fig. 3). Dispersal of larvae of the Spratly islands reef ecosystems may contribute to the production of fish and other seafood coral reefs in nearby regions. Thus, coral reefs in the archipelago can be seen as a "savings bank" where the commercially important invertebrate and fish are preserved from overfishing, and this is a constant flow of maggots to areas depleted marine resources.

\section{Conclusions}

In broad terms, the Spratly islands reefs are important ecologically, with abundant and relatively undeveloped resources, which have undergone depression coastal species still abound.Is currently in a complex dispute over the Spratly islands being involved Vietnam, China, Malaysia, Taiwan and the Philippines claim all the is lands in China and Vietnam; of them want to annex the Philippines Malaysia. Brunei in 1984 established an exclusive fishing zone encompassing Louisa Reef in the southern part of the archipelago without public ownership in their islands. In the year 2000, China jo ined the ASEAN discussions to establish for the South China Sea "code of conduct" - is not a legally binding measure, to resolve the problems between the countries involved in the dispute on the Spratly islands. Mind and proposal Mack Manus[1] on the conservation of genetic diversity of reef ecosystems and the region, it proposed to establish cross-border international maritime reserve zone 
(Park, Reserve) Spratly archipelago under possible protectorate of Vietnam, China and the Philippines.

\section{ACKNOWLEDGEMENTS}

The authors are grateful to the authorities of the A.V. Zhi rmunsky institute of marine biology FEB RAS (Vladivostok, Russia) and the Institute of Oceanography (Nha Trang, Vietnam) for financial security of the expeditions.

\section{REFERENCES}

[1] J.W.McManus,"The Spratly islands. a marine' park?”,Ambio. V.3.pp.181-186,1994

[2] B. V. Preobrazhenski, "Report of Vietnam-Soviet cooperative expedition by vessel Kallisto and Berill, from 17 February to 12 June 1981”, Institute of Oceanography, Nha Trang, 1981. (In Russian)

[3] N.H.Yet,"Some data on reef-building corals in Song Tu island group of Spratly archipelago",Mar.Rres. Environ. Sci. Techn. Publ. House. Hanoi. pp. 135-143,1991.(inVietnamese)

[4] N. H.Yet, "Marine biological resources and ecosystems",M Monography of Vietnam Sea. T. IV. Hanoi. pp. 387-420, 1994.

[5] . H. Yet, “Thànhphânloài san hôcúngvàcâutrúc rąn san ho dao thuy nchai (QuânĐáoTruờngSa)”,Tàin guy nvà moi truờngbiển.Tâp IV.pp. 299-312, 1997. (inVietnamese)

[6] N. H. Yet, L. V.Ken, "Some Data on Species Composition and Distribution of Scleractinian Corals in Ha LongBay," Journal of Biology, vol. 18, pp. 7-13,1996.

[7] V. S. Tuan, N.H. Yet, P.M. Alino, "Coral and coral reefs in the north of the Spratly archipelago - the result of RP-VN jomes-scs 1996", in Proceeding Science Conference RP-VN JOM SRF-SCA 96. Hanoi. p.87-101, 1997.

[8] Yu.Ya.Latypov,"Spratly archipelago as a potential recovere reserve of biodiversity of coastal and islands reef of Vietnam", in/ Proceedings of the Workshop Coastal marine biodiversity and bioresourse of Vietnam and adjacent areas to the South China Sea Nha Trang, Vietnam, November 24-25, 2011, Vladivostok-Nha Trang, 2011, p. 55-59.

[9] Veron J.E.N."Corals in space and time: the biogeo graphy and evolution of the Scleractinia", Australian Institute of Marine Science.321 p.1995.

[10] Yu.Ya.Latypov, "Scleractinian corals and reefs of Vietnam as a part of the pacific reef ecosystem", Open Journal of Marine Science, vol. 1, pp. 50-68, 2011.

[11] J.E.N Veron., G.Hodgson,"Annotated checklist of the hermatypic corals of the Philippines", Pacific Science,vol. 43. pp. 234-287, 1989.

[12] Y.Loya, L.B. Slobodkin, "The coral reefs of Elate (Gulf of Elate, Red Sea)", Journal Sample Zoological Society of London, vol. 28, 117-140, 1971.

[13] G.J. Bakus, "Quantitative ecology and marine biology”. A.A. Balkema. Rosterdam1990.

[14] T.ASerensen,"Method of establishing groups of equal amplitude in plant sociology based on similarity of species content and its application to analyses of the vegetation on Danish commons"// Biol. Scr,. vol. 5.pp. 1-34, 1948.

[15] N. H. Yet, "San hôờquândảoTruờng Sa. Tap chíSinh hoc", no. 1.Trang 387-420,1989.(in Vietnamese)

[16] N. H. Yet, V. S. Tuan, L. V. Ken, Hard coral in Spratly archipelago. J. Biology. no. 1. pp. 33-36, 1989. (inVietnamese)

[17] C.F. Dai, T.Y. Fan, “Coral fauna of TaipingIsland (ItuAbaIsland) in the Spratly of the South China Sea", Atoll res. Bull. 1996. no. 436, pp. 1-21,1966.

[18] Y. Y. Latypov, "Macrobenthos Communities on Reefs ofthe an Thoi Archipelago of the South China Sea," Russian Journal of Marine Biology, vol. 26, n. 1, pp.18-26, 2000

[19] Yu.Ya.Latypov,Coral reefs of Vietnam.M.: Nauka.2007. 